\title{
Spinal Cord Part
}

National Cancer Institute

\section{Source}

National Cancer Institute. Spinal Cord Part. NCI Thesaurus. Code C33969.

Any component of the central nervous system contained within the spinal column or the vertebral canal. 